\title{
THE OBLIGATION OF NOTARY TO REPORT SUSPICIOUS FINANCIAL TRANSACTIONS BASED ON THE VALUE OF THE TRANSACTION
}

\author{
Ilham Zain Fadila, Bambang Sugiri, Diah Aju Wisnuwardhani \\ Universitas Brawijaya, Indonesia \\ Email: ilhamzainfadila@gmail.com
}

Abstract

Government makes various efforts to prevent the crime of money laundering. One of them is to encourage some parties to participate in supervising the suspicious financial transaction. In its practice, this triggers juridical problem such as verification and monitoring policies of financial transaction on the service users by the notaries. This research aims to describe the notary's criteria and legal responsibilities on the suspicious transaction. This article is based on the doctrinal legal research with statute and conceptual approaches. The research result shows that the criteria of suspicious financial transaction have been set in Indonesian legislation. The notary has legal responsibility to identify and verify the service users of authentic deed issue in implementing precautionary principles. This responsibility is accompanied by administrative sanction which is in line with the Regulation of the Minister of Law and Human Rights No. 9 of 2017, concerning the Implementation of Knowing Your Customer Principles for the Notary.

Pemerintah melakukan berbagai upaya mencegah terjadinya tindak pidanapencucian uang. Salah satunya, mendorong berbagai pihak untuk turut serta mengawasi terjadinya traksaksi keuangan yang mencurigakan. Dalam pelaksanaannya, upaya ini menimbulkan problem yuridis. Seperti kebijakan verifikasi dan pemantauan transaksi keuangan pengguna jasa oleh notaris. Penelitian ini bertujuan untuk mendeskripsikan kriteria dan tanggung jawab hukum notaris terhadap terjadinya transaksi keuangan mencurigakan. Artikel ini berdasarkan penelitian bukum doktrinal, dengan pendekatan perundang-undangan dan pendekatan konseptual. Hasil penelitian menunjukkan babwa kriteria transaksi keuangan menurigakan sudah diatur dalam peraturan perundang-undangan di Indonesia. Notaris memiliki 
tanggung jawab hukum untuk mengidentifikasi dan memverifikasi pengguna jasa pembuatan akta autentik dalam rangka penerapan prinsip kehati-hatian. Tanggung jawab ini disertai sanksi administrasi sesuai Peraturan Menteri Hukum dan Hak Asasi Manusia Nomor 9 tahun 2017 tentang Penerapan Prinsip Mengenali Pengguna Jasa Bagi Notaris.

Keywords: financial transaction, money laundering, notary.

\section{Introduction}

Human beings form legal institutions that govern the lives of people as social beings. The development of society's needs from time to time involves developing laws capable of reacting to the increasingly developing human life problems.

Legal certainty has a vital role in protecting the pattern of people's actions from instability in human lives, leading to a societal saturation of the law to guide people's lives. The need for legal clarity in an ever more rapid development needs a strong and stable public service sector to guarantee its lawful rights and obligations.

It is essential to ensure the required certainty and legal security in written documentation of an authentic nature concerning legal actions, agreements, stipulations, and acts before or by a competent official. A notary is an official who has the authority because it is regulated by law in civil law services to make authentic deeds as stated in Article 1 number (1) of Law Number 30 of 2004 concerning the Position of Notary (State Gazette of the Republic of Indonesia, 2004, Number 117, Supplement to the State Gazette of the Republic of Indonesia Number 4432), which was amended by Law Number 2 of 2014, (State Gazette of the Republic of Indonesia Number 5491), in which the two laws are considered as one unit (hereinafter referred to as UUJN), states that "Notary is a public official, authorized to make authentic deeds and have other powers, as referred to in this law, or based on other laws."

A notary is a public officer designated by the state to help the public create authentic deeds and other authority under current laws or daily lives. A notary's roles and competencies relate closely to the agreements, acts, and conditions required by statutory regulations and that are set out in the authentic deed or wanted by the interested parties. The deed then imposes rights and obligations between the parties, guaranteeing or presenting proof of specific actions, agreements, and provisions to provide legal certainty for the parties concerned. ${ }^{1}$

1 M.U Sembiring, Technique of Deed Making, (North Sumatra: Notariat Specialist Education Program, Faculty of Law, University of North Sumatra, 1997), 3. 
Notary in carrying out his profession is subject to the provisions of UUJN, namely Law on Notary Position Number 2 of 2014, concerning Amendments to Law Number 30 of 2004 concerning the Position of Notary Public.

With the issuance of Government Regulation of the Republic of Indonesia No 43 of 2015 concerning Reporting Parties to Money Laundering, Article 3 states that the reporting parties include the following professions: Lawyer, Notary, Land Titles Registrar, Accountant, Public Accountant, and Financial Planner, which are governed by the Government Regulation in its implementation. Establishment of Government Regulation (PP) No. 43 of 2015 concerning Reporting Parties in the Prevention and Eradication of Money Laundering adds several other parties as reporting parties, and one of them is a notary. This is relevant because notaries, in carrying out their duties, have been vulnerable to being manipulated by money laundering suspects to conceal or disguise their properties from the proceeds of criminal acts.

There are a variety of concepts of money laundering. In general, these meanings or definitions are not much different from one another. Black's Law Dictionary defines money laundering as term used to describe investment or other transfer of money flowing from racketeeting, drug transaction, and other illegal sources into legitimate channels so that is original source cannot be traced. ${ }^{2}$ That in its free translation, money laundering is a term for money earned illegally and invested in legal fields and through legal channels so that the money's origin can no longer be identified. Based on this definition, money laundering may be a method of eliminating traces of the origin of money from illicit or fraudulent activity through a series of repetitive investment activities or transactions to gain legal status for money invested or entered into the financial system.

Money laundering is a crime with unique characteristics and a starting point for eradicating economic crime, namely eradicating the initial crime and the pursuit of the proceeds of crime through the enforcement of anti-money laundering legislation. This provision can catch the perpetrator of the origin of the crime and sniff out the proceeds from the crime flow. Through the application of anti-money laundering provisions accompanying predicate crimes, law enforcement authorities can collect 2 (two things) at once, namely the arrest of the perpetrators of predicate crimes and at the same time, the return of money laundering proceeds to those who have the right. ${ }^{3}$

2 Henry Campbell Black, Black's Law Dictionary Sixth Edition, (St. Paul MinnL: West Publishing Co., 1990), 884

3 Yenti Ganarsih, Law Enforcement against Money Laundering and Problems in Indonesia, (Jakarta: PT. Rajagrafindo Persada, 2015), 1. 
Money laundering can be defined as using money generated by illegal activity or against the criminal's law by keeping his identity secret and hiding the money's origin. Also, the criminal turns the money into properties that are recognizable or come from legal sources. ${ }^{4}$

The perpetrators of white-collar crimes are somewhat different from most traditional offenders because the perpetrators of white-collar crimes are typically well-respected individuals who have a high degree of education. Money laundering is a procedure or an operation that uses the proceeds of a criminal act, and the defendant hides or disguises the origin of the money as if it were an acquisition from a legitimate business. ${ }^{5}$

Indonesia is committed to combating the crime of money laundering, and its concrete actions can be seen in 2002. The Government of Indonesia, along with the Indonesian House of Representatives (DPR), enacted Law No. 15 of 2002 on the Crime of Money Laundering and amended Law No. 25 of 2003 on its amendments in the following year. However, in politics and state life, the Indonesian government is faced with many new findings related to money laundering cases and many items that were not regulated in the old legislation. Therefore, the government needs a factual legal basis to ensure law enforcement's certainty and efficacy and the tracing and recovering assets from illegal activities. To answer this problem, the government issue a new Law No. 8 of 2010 on the Prevention and Eradication of Money Laundering (in the future referred to as the TPPU Act) and is still in force today. Many parties hope that the TPPU Law will be able to eradicate transnational money laundering crimes.

The government has also formed an independent and specialized agency to assist law enforcement against money laundering by establishing the Financial Transaction Reports and Analysis Center (PPATK). PPATK is an independent institution that oversees all transactions deemed suspicious. This institution also functions as a financial intelligence unit that receives various reports on any suspicious transactions.

This is further emphasized in the provisions of Article 39 of the TPPU Law, which states that PPATK has the task of preventing and eradicating the crime of money laundering. In carrying out its duties and functions, PPATK collaborates with several parties, both government agencies and private institutions, such as Financial Service Providers and Providers of goods and services, as reporting

4 David Chaikin and J.C Sharman, Corruption and Money Laundering, (United States: Palgrave Macmillan, 2009), 14.

5 Juni Sjafrien Jahja, Fight Against Money Laundering, (Jakarta: Visi Media, 2012), 5. 
parties must submit a suspicious transaction report. ${ }^{6}$

Article 44 of Law Number 8 the Year 2010 concerning the Prevention of Money Laundering also regulates the importance of carrying out the duties of the PPATK, which may request information from parties suspected of having indications of the Crime of Money Laundering. One of the parties that may be asked for such information is a notary because the perpetrator of the crime of money laundering can also use the services of a notary to obtain legal validity.

Money laundering has such a huge impact and has a neat and covert system that encourages all parties to participate. The government anticipates Money Laundering by making Government Regulation (PP) Number 43 of 2015 concerning Reporting Parties in the Prevention and Eradication of Money Laundering (later is known as PP PPPU). This PP regulates several new reporting parties as referred to in Article 3 of the PP, and one of them is a Notary who is obliged to report transactions deemed suspicious.

The obligation to report is contained in Article 3 letter b of Government Regulation Number 43 of 2015 concerning Reporting Parties in the Prevention and Eradication of money laundering. Notaries are included in the "Reporting Parties" who are obliged to report to PPATK any suspicious transactions related to suspected money laundering. Besides, Article 4 of Government Regulation Number 43 of 2015 states that Notaries are required to apply the principle of recognizing service users or clients.

The Ministry of Law and Human Rights, the Directorate General of General Legal Administration, the Financial Transaction Reports and Analysis Center (PPATK), and the Indonesian Notary Association (INI) are also collaborating to combat the crime of money laundering. They issue a Joint Announcement, which requires Notaries to register and report the prevention and eradication of money laundering in the Gathering Reports \& Information Processing System (GRIPS) application.

The GRIPS application is present as a form of support for joint commitment to prevent and eradicate the crime of money laundering and as a form of the Indonesian government's obligations in international forums such as the FATF. Therefore, the obligation of notaries to register and report suspicious financial transactions through the GRIPS PPATK application refers to the Regulation of the Head of the Financial Transaction Reports and Analysis Center Number 11 of 2016, concerning Procedures for Submitting Suspicious Financial Transaction

6 Wiyono, Discussion of the Law on the Prevention and Eradication of Money Laundering, Jakarta: Sinar Grafika, 2014), 5. 
Reports for Professions (Perka PPATK 11/2016). ${ }^{7}$

Following the Joint Announcement, Notaries are required to register in the GRIPS PPATK application until due on May 6, 2019. Starting May 7, 2019, sanctions will be imposed in the form of a temporary closure of access to AHU Online for Notaries who have not completed these obligations. Besides, Perka PPATK 11/2016 also provides administrative sanctions to professions that do not carry out their obligations in the form of written warnings, announcements to the public regarding actions or sanctions and/or administrative fines.

The presence of PP No. 43 of 2015, concerning PPTPPU Reporting Parties and Head of PPATK Regulation No. 11 of 2016, as well as Regulation of the Minister of Law and Human Rights, Number 9 of 2017, regarding the obligation for Notaries to apply the Principles of Recognizing Service Users (PMPJ) especially the obligation to carry out verification, monitoring, and the reporting turns out to be inconsistent with or disharmonious with the Oath of Position and the Code of Ethics for the Notary profession, the essence of the duties and functions of the notary seems to have been intervened by presenting an interest that leads to fiscal (economic) interests. A notary should not prejudice anyone who comes before him, everyone who comes to him has the right to be accepted and treated in good faith, and this is the ethics of a profession that must be upheld. The identification made by the notary is only limited to the truth of the client's identity, and it is not appropriate for the notary to verify or check the truth of the identity shown by the client. Similar to the obligation for notaries to monitor service users' transactions, this is clearly outside the context of the notary profession's obligations and authorities.

The Financial Transaction Reports and Analysis Center (PPATK) released data, and it was noted that only a few reporting parties had yet fulfilled the obligation to submit financial transaction reports. Currently, many reporting parties have not registered their companies through the Gathering Report and Information Processing System (GRIPS) applications. PPATK notes that the professional sector is the party that reports the least amount of registering financial transaction reports. Until the end of 2017, the number of reporting parties with professions was only $0.1 \%$ of 64,604 . Meanwhile, reporting parties from non-bank financial service providers currently have reached $75 \%$ of a total of 2,307. Meanwhile, bank financial service providers have reached $97.8 \%$ of the total 1,922 reporting parties. This data indicates that there is still confusion regarding the criteria and meaning of suspicious financial

7 The Indonesian Notary Association, "Registration of the GRIPS Application at PPATK," https:// ini.id/post/pend Registration- application-grips-di-ppatk, accessed January 31, 2020. 
transactions and needs to be reported by a notary to the PPATK.

Notaries should be vigilant, especially in payments that use the transaction mode to cut off the fund source monitoring. However, there is no standard feature of the current development about how a transaction can be deemed suspicious by a public notary. The trend and mode of money laundering have changed. In the past, the focus of the mode of money laundering was banking institutions. However, as Indonesia's banking institutions became tighter, the money laundering method moved towards the purchase and sale of land. This mode is closely related to using the notary's instrument in explicitly ratifying the selling and purchase agreement for the property.

From the above explanation and data, the authors are interested in raising this title to see how a notary determines the meaning and criteria of suspicious financial transactions reported to the PPATK. The notary does not yet have a clear explanation and still have multiple interpretations regarding Suspicious Financial Transaction in that regulation. In carrying out professional activities, they are expected to implement the Principles, Know Your Customer Principles, as the reporting party in TPPU, according to the Regulation of the Minister of Law and Human Rights Number 9 of 2017. However, the suspicious transaction's size and purpose to be reported are still unknown and, among notaries, have several interpretations.

Many suspicious financial transactions occur in Indonesia via the banking system. Under Law No 8 of 2010, on the Prevention and Eradication of the Crime of Money Laundering, suspicious financial transactions defines as follows:

1. Financial transactions that deviate from the customer's profile, attributes, or transaction patterns.

2. Financial transactions by clients which are relatively predictable to avoid the reporting of the transactions concerned that are required to be performed by providers of financial services in compliance with the provisions of this Law

3. Financial transactions, carried out or canceled, using assets suspected of having been obtained from proceeds of crime; or,

4. The financial transactions demanded by PPATK to be reported by the reporting parties as involving assets are alleged to have derived from the crime proceeds.

So, suspicious financial transactions do not have typical characteristics because variations and developments influence them in services and existing financial 
instruments. Based on these problems, further research is needed regarding the meaning and clear criteria regarding Suspicious Financial Transactions contained in existing regulations.

Based on the descriptions above, this thesis research will focus on the meaning and criteria for suspicious transaction value-based transactions that need to be reported by a Notary Public to PPATK, which will be included in the thesis research entitled "Notary Obligations to Report Suspicious Financial Transactions on a basis Transaction Value."

The novelty of this study is to understand the purpose, meaning, and criteria for suspicious financial transactions to be reported to the PPATK by a notary public and the application of the notary profession in applying the Principle Know Your Customer. Much current research, such as that performed by Ira Quwaity Saragih, has shown that several legal disputes have emerged between the UUJN regarding the confidentiality of the deed's contents vs. its duty to disclose suspicious financial transactions. These two contradictory things become the reasons for notaries to be included as one of the reporting parties mentioned in Government Regulation No. 43 of $2015 .{ }^{8}$ Florenshia researched with a similar theme focusing on the regulation of notaries' obligations in reporting suspicious financial transactions related to money laundering and legal protection to notaries as reporting parties and analyzing legal regulations regarding money laundering in Indonesia. ${ }^{9}$ Daniella Herera Yosifany Hutagalung examines the notary profession's legislative ratio as one of the reporting parties for suspicious financial transactions and legal protection for notaries with good intentions to report suspicious financial transactions. ${ }^{10}$

\section{Research Methods}

This type of research is normative research because it relates to the notary's duty to keep deeds secret concerning a reporting party for suspicious financial transactions. The author uses the statutory analysis method (statute approach) because the aim of this study is the various legal rules that are the focus as well as the central theme of research and computational analysis (suspicious coding criteria and compulsory financial transactions) to create a new mandatory definition for financial transactions and has to be reported to PPATK. The researcher

8 Ira Quwaity Saragih, Juridical Analysis of the Notary's Obligation to Keep a Deed, Related to Article 3 of Government Regulation Number 43 of 2015 Regarding Notaries as Reporting Parties in Efforts to Prevent and Eradicate Money Laundering, Journal Premise Law, Vol 13 of 2013: 1.

9 Florenshia, Juridical Analysis of Notary Obligations in Reporting Suspicious Financial Transactions in the Anti Money Laundering Regime, Premise Law Journal, Vol. 9 of 2019: 4.

10 Daniella Herera Yosifany Hutagalung, Legal Protection of Notaries and PPAT as Reporting Parties in the Crime of Money Laundering, Jatiswara, Vol 35 No. 1 (2020): 10. 
explores the origins of law that consist of primary law, general law, and even law through library studies. These legal materials were examined using several legal interpretations, including (1) The interpretation of grammar, as an attempt to represent and show the notary's duty to report suspicious Financial Transactions (Know Your Customer Service Principles). (2) Systematic interpretation provides a much broader or more accurate sense than what it means to be good people; (3) The interpretation is more important, namely as an attempt to interpret suspicious Transactions that must be reported by a notary public the Financial Reporting and Analysis Center. In Government Regulation Number 43 of 2015, relating reporting parties in the prevention of suspicious financial transactions, as well as Regulation of the Minister of Law and Human Rights No. 9 of 2017, concerning the Implementation of Knowing Your Customer Principles, there are vague statements as to the definitions and conditions to be stated by a notary.

\section{Meaning and Criteria for Suspicious Financial Transactions}

In general, law shows a normative view of an entity that only recognizes human conduct or acts that are based on and defined by legal norms. The law science itself describes the legal norms created by human actions or activities defined, observed, and enforced by those actions or behaviors, thereby explaining the normative relationship between the facts formed by those norms. Humans, as social beings, are, of course, interlinked in the establishment of these norms between each person and the other. Besides, human nature has been one of having a harmonious and healthy relationship; in other words, human beings often need rules that can govern a relationship in the right, balanced, secure, and peaceful manner.

According to the Standardized Indonesian Dictionary, the definition of a word transaction comes from a word transaction of sale and purchase agreement between two parties. In contrast, a financial transaction is an occurrence within a business that involves a chronological, systematic, and orderly record of assets, debt, and capital changes. ${ }^{11}$ The transaction is an operation of a corporation that induces adjustments in the status of the financial assets of the company, such as, for example, selling, purchasing, paying wages, and paying various other costs. ${ }^{12}$

The transaction is an operation carried out by an individual that creates adjustments in assets or finances (increase or decrease) that are owned, for example,

11 The meaning of the word Transaction, according to the Standardized Indonesian Dictionary (KBBI). Accessed June 12, 2020.

12 Abdulkadir Muhammad, Law of Indonesian Companies, (Bandung: PT. Citra Aditya Bakti, 2018), 4. 
by selling land, purchasing goods, paying debts, and paying different costs to meet a living need and handling the transaction. Financial transactions are economic operations in the company's subsystem or incidents in the company's units. The purpose of the calculation can be evaluated in currency values and may influence the accounting system's financial statements. Financial transactions may also be viewed as an economic occurrence affecting the company's assets and equity, which are converted into growing and declining accounts and calculated in monetary units. $^{13}$

The recommendation to record financial transactions in Islamic law is an order from Allah SWT in the Koran in Chapter 2 verse 282 with the following translation: "O you who believe! If you make a debt or credit (transact) for a specified time, let you write it down (record and book it). And let a writer among you write correctly. Don't the writer refuse to write it down as Allah has taught him, so let him write it down. O you who have believed, when you contract a debt for a specified term, write it down. And let a scribe write [it] between you in justice. Let no scribe refuse to write as Allah has taught him. So let him write and let the one who has the obligation dictate. And let him fear Allah, his Lord, and not leave anything out of it." Furthermore, in the next paragraph it is stated that: "... And do not be [too] weary to write it, whether it is small or large, for its [specified] term. That is more just in the sight of Allah and stronger as evidence and more likely to prevent doubt between you, except when it is an immediate transaction which you conduct among yourselves. For [then] there is no blame upon you if you do not write it."

Recording financial transactions are also part of Muamalat, which essentially affects revenue, expenses, assets, and liabilities. Recording and sharia are responsibilities as set out in the Koran. ${ }^{14}$ Financial transactions have a value or are represented in money units and are very influential in the company's financial state or the organizational entity because of transactions happening within the company. We can see how the company uses the company's economic capital and how to raise funds that can be used to support these operations. ${ }^{15}$

Although non-financial transactions can be described as an event that is processed by a management information system that has a broader significance than financial transactions, such as the signing of a cooperation agreement

13 Mardi, Accounting Information Systems (Bogor: Ghalia Indonesia Publisher, 2011), 7.

14 Mhd. Syahman Sitompul, Nurlaila, Hendra Harmain, Implementation of Surat al-Baqarah Verse 282, In the Accountability of Mosques in East Sumatra, Human Falab: Volume 3. No. July 02 - December 2016: 205.

15 Agus Budiarto, Legal Position, and Responsibilities of Limited Liability Company Founders, (Bogor: Ghalia Indonesia, 2009), 5. 
(MoU) between a company and another company related to the procurement of raw materials for production. This incident can be recorded by the company's information system as a transaction.

Financial transactions are economic operations that impact the assets and equity and are expressed in different accounts and calculated in different financial measures. Examples of financial transactions involve buying a supplier's inventory, selling goods to consumers, and obtaining cash. This form of transaction is legally binding on all entities involved in financial transactions. ${ }^{16}$

Non-financial transactions are all things that are processed by the organization via the information system but which do not follow the explicit meaning of financial transactions. An example of a non-financial transaction, namely the addition of a new supplier of raw materials to a list of previously valid suppliers, is an operation that can be processed by the company's information system as a transaction. The consequence of the processing of non-financial transactions may be deciding to put an order with the new supplier.

Many suspicious financial transactions are happening in Indonesia via the banking system. ${ }^{17}$ The benchmark for suspicious financial transactions is set out in Article 1 paragraph (5) of the Money Laundering Act and Article 1(8) of Government Regulation No 43 of 2015 concerning the PPTPPU Reporting Party, which also regulates:

1. Financial transactions that deviate from the profile, characteristics, or history of transactions of the respective Service User;

2. Financial transactions by service users reasonably suspected of having been carried out to prevent the reporting of the transaction involved, which must be carried out by the reporting party in compliance with the provisions of the laws and regulations on the prevention and eradication of money laundering;

3. Financial transactions carried out or cancelled by using properties suspected of coming from proceeds of crime;

4. Financial transactions demanded by PPATK to be reported by the Reporting Parties because they contain properties suspected of originating from proceeds of illegal activity.

So, essentially suspicious financial transactions do not have uniform characteristics since they are affected by variations and innovations in existing

16 Binoto Nadapdap, Law of Limited Liability Companies (Jakarta: Permata Aksara, 2012), 12.

17 Raisa Maria Sapulete, Suspicious Financial Transactions, According to Law Number 8 Year 2010, Regulating Anti Money Laundering, Lex et Societatis, Vol. I / No.2 / Apr-Jun / 2013: 148. 
financial services and instruments.

The author takes a variety of notary opinions on the meaning and interpretation of suspicious financial transactions as set out in current laws and regulations, beginning with Law No. 8 of 2010 on Money Laundering, Government Regulation No. 43 of 2015, and Permenkumham No. 9 of 2017, on the concept of identification of service users. In the following, the researcher presents a range of opinions from several notaries on this subject. According to Didik Wasis Subekti, SH, one of the senior notaries in Magetan Regency, reported that the definition and understanding of suspicious financial transactions are not carried out as usual and transactions that include various items that cannot be carried out by service users. However, according to him, the definition of suspicious financial transactions defined in the current laws and regulations still appears to apply to transactions in the banking sector and, it cannot be generalized to the world of the notary profession. There are still many suspicious financial transactions in the Notary Public, particularly notaries in Magetan Regency. The number of interpretations regarding suspicious financial transactions among notaries, especially notaries in Magetan Regency, has triggered the lack of reporting suspicious financial transactions to the financial transaction reporting and analysis center (PPATK). ${ }^{18}$

Referring to existing regulations, the minimum transaction limit that must be reported to the PPATK is too low because of the assumption that each notary's value must be different in interpreting it. According to him, the transaction that needs to be suspected is a minimum of Rp.300,000,000 because when the minimum transaction threshold is too low, there will be too many reports that must be submitted to PPATK. According to Feliyanti SH, notary in Magetan Regency and at the same time director of the Magetan Regency Regional Supervisory Board, suspicious financial transactions are transactions made by service users; however, there is a significant difference between the value of the job and transaction. For example, transactions are carried out by motorcycle taxi drivers, but transactions in a great value, so it is crucial to add more precautionary principles to such cases.

Meanwhile, according to Notary Feliyanti, financial transactions that need to be reported to PPATK are at least Rp. 500,000,000. The two examples listed by the researcher indicate that the transaction's value differs from one notary to another. However, it is specified in the Regulations that the statement of service user transactions is considered suspicious or is not returned to the notary's opinion so that it becomes one of the factors triggering the low reporting of suspicious

18 Result of an interview with Notary Mei Herlina, SH. Magetan District Notary, regarding the meaning of suspicious financial transactions, on 12-06-2020. 
financial transactions by notaries.

According to Mei Herlina, SH, one of the senior notaries in Magetan Regency claimed that suspicious financial transactions could be suspected and needed to be suspected because they came from an illegally acquired property or material, whether it was corruption or other criminal activities. He also argued that the definition of suspicious financial transactions, as defined in the laws and regulations, still appears to apply to transactions in the banking sector and, according to him, cannot be extended to the notary profession. There are still many interpretations of suspicious financial transactions between notaries, particularly notaries in Magetan Regency. However, there has never been any reporting of suspicious financial transactions to PPATK in Magetan Regency.

According to Endang Sri Kwuryan.SH, M.Kn, a suspicious financial transaction that does not come from the service user's own finance. It could be that the money used in a transaction using a notary service is money deposited, and it could be that the money deposited came from the wrong and illegal sources. Determining the meaning of suspicious financial transactions in existing regulations is still biased and confusing, especially for the notary profession because there are no clear characteristics and indicators that can classify transactions carried out by service users who face the notary as suspicious or not.

According to Endang Sri Kwuryan, SH, M.Kn, a suspicious financial transaction is a transaction that does not originate from the service user's own funds, it could be that the money used in a transaction using a notary service is money deposited, and it could be that the money deposited comes from incorrect and illegal sources. Determining the significance of suspicious financial transactions in current legislation is still biased and confusing, particularly for the notary profession, since there are no specific characteristics and indicators that can identify transactions carried out by service users as suspicious or not. ${ }^{19}$

According to the Notary Imam Rahmat Sjafi'i, SH, as the head of the Malang city notary association, suspicious financial transactions are out of the ordinary with a value of more than Rp. 1000,000,000. performed by service users. Indeed, the benchmark for determining suspicious financial transactions used is still from Law No. 8 of 2010, concerning the crime of money laundering, which is more regulated for financial institutions such as banks. As a professional, the notary has difficulties determining the category of transactions carried out by these service users, suspicious or not, because the notary only determines the

19 Result of an interview with Notary Mei Herlina, SH. Magetan District Notary, regarding the meaning of suspicious financial transactions, on 12-06-2020. 
transaction's formal truth. ${ }^{20}$

The key feature of money laundering is a crime committed as a Double Follow Up Crime, whilst the original crime is referred to as a Predicate Deffens or Core Crime or illegal activity, namely the original crime produces money that is then carried out through the laundering process. The duty of the notary to apply PMPJ is carried out in commercial ties with service users; ${ }^{21}$ there are financial transactions in rupiah currency and/or foreign currency of at least or equivalent value to Rp. 100,000,000.,-(hundred million rupiahs). There are financial transactions linked to money laundering and terrorist funding, and the notary has doubts about the authenticity of the details reported by service users.

As a transnational organized crime, the growth of money laundering has become a challenge for all countries in the world to support mutual commitments to prevent and eliminate money laundering. Law No. 8 of 2010, on the Prevention and Eradication of Crime of Money Laundering (PPTPPU Law), does not provide a detailed description of what is meant by money laundering. It only states that 'money laundering is any act that fulfills the elements of a criminal act in compliance with the provisions of that law.' Various provisions, guidelines, and international conventions on money laundering and the implications and possible losses have been drawn up and collected up to now. There are at least three reasons for criminals to carry out money laundering, including worries about dealing with tax agents, arrest by law enforcement authorities, and confiscation of crime proceeds because they have been acquired illegally. ${ }^{22}$

Based on data from PPATK, it can be seen that the total number of suspicious transactions increased from January 2003 to September 2018. The number of reports received by PPATK by September 2018 was 63,429,486. There was a rise in suspicious transaction reports to 408,088 or an increase of $13,9 \%$ compared to the high-risk areas in December 2017, namely DKI Jakarta, East Java, Papua, and North Sumatra. ${ }^{23}$

Financial institutions have an essential role in applying the principle of recognizing Service Users and reporting certain transactions to the authorities as

20 Result of an interview with Notary Endang Sri Kawuryan, SH. M.Kn., Notary of Malang City, regarding the meaning of suspicious financial transactions, on 14-06-2020.

21 Result of an interview with Notary Imam Rahmat Sjafi'I SH. Notary of Malang City, regarding the meaning of suspicious financial transactions, on 13-06-2020.

22 Nurananda Budi Muliani, Pieter Everhardus Latumeten, Widodo Suryandono, Notary Responsibilities as Reporters of Suspicious Financial Transactions in the Gathering Reports \& Information Processing System (GRIPS) Application, Notary, Vol 1, No. 003 (2019): 201.

23 PPATK, Statistical Bulletin of Anti Money Laundering and Terrorism Funding, Volume 103 / Thn IX / 2018 September 2018 
material for analysis and subsequently submitted to investigators. Thus, banks or other financial service companies must reduce their risk to be used as a means of money laundering. Recognizing and knowing the identity of customers, monitoring transactions, and maintaining customer profiles, and reporting, "suspicious transactions conducted by parties using bank services or other financial service companies," must be applied well.

Any individual conducting transactions with a bank is required to fill out the form issued by the bank and attach supporting documents containing the correct and required identification and details containing his/her identity, source of funds, and intent. The authenticity of the identity and details provided by service users (prospective customers) and their supporting documentation must also be checked by examining these supporting documents based on documents and/or other sources of information that are credible and independent and ensure that the data is up-to-date. PPATK defines the Principle of Recognizing Service Users (PMPJ) as the principle applied by reporting parties to assess service users' background and identity, track transactions, and report transactions to the competent authority. Parties that can report include financial service providers (PJK) are finance companies, insurance companies, insurance brokers, pension funds, financial institutions, securities companies, investment managers, custodians, trustees, foreign exchange traders, payment instrument operators using cards, electronic money administrators, savings and loan cooperatives, pawnshops, commodity futures trading companies, and money transfer business activity organizers or other Goods and or Service Providers (PBJ) such as property companies, motor vehicle traders, jewelry or precious metal traders, merchants arts and antic, and auction hall. In this case, according to the author, the notary can also do this if, in carrying out his duties, he finds a suspicious transaction.

There are many ways to recognize irregular financial transactions or circumstances that are sometimes used as a means of money laundering. Types of examples of transactions that can be classified as suspicious transactions are as follows:

1. Suspicious transactions using a pattern of cash transactions.

a. Huge cash deposits by individuals or corporations engaged in some business activities and usually made by check or other non-cash instruments;

b. Increase in cash deposits that are very material in a person or company account without sufficient explanation, in particular where the cash deposit 
is moved directly to a destination that has no connection or relationship with the individual or company;

c. Cash deposit using several small deposits slips so that the total amount of the deposit is substantial;

d. The use of company accounts, which are generally carried out through checks or other non-cash instruments but are carried out in cash;

e. Payment or cash deposit for settlement of bills, transfers, or other instruments of the money market;

f. Tiny denominations of cash trade-in enormous quantities, depending on the scale of the bank office;

g. Strong frequency of foreign currency exchange;

h. Increase in cash processing activities in a vast number due to the size of the bank office;

i. Cash deposits in which there is often counterfeit money;

j. Transfers in bulk from or to other countries with cash payment instructions.

k. Deposit significant sums of cash into a deposit account during working hours in cash to prevent direct contact with bank officers.

2. Suspicious transactions with bank accounts.

a. Maintenance of many accounts on behalf of other parties which are incompatible with the form of business operation of the customer;

b. Small cash deposits in many accounts held by the bank's clients, so that the overall deposits are very large;

c. Fund deposits or withdrawals in large sums from a person or company account that are not acceptable or not relevant to the business of the customer;

d. Providing information that is difficult to prove or that requires a very high fee for the bank to prove it;

e. Payments from consumer accounts made after cash deposits were made to the account on the same day or the previous day;

f. Huge withdrawals from customer accounts that were previously inactive or from accounts of customers receiving large foreign deposits;

g. Use of separate teller officers for consumers who carry out large quantities of cash transactions or transactions simultaneously. Parties representing the company shall always avoid contact with bank officers;

h. Significant increase in cash deposits or negotiable instruments by a corporation using the client accounts of the company, in particular where the deposits are directly exchanged between other client accounts; 
i. Refusal of the customer to provide additional essential documents or information which, if provided, will allow the customer to become eligible for credit extension facilities or other banking services;

j. Rejection of common banking facilities by customers, such as refusal to offer a higher interest rate on a certain amount of balance.

k. Deposit for profit on the same account by several parties without sufficient explanation.

3. Suspicious transactions by related investment transactions.

a. Purchase of securities for safekeeping at the bank as custodian, which should not be sufficient when considering the credibility or financial ability of the customer;

b. Back-to-back deposit/credit transfers between the bank and its branches, associated companies or financial institutions in other countries known as countries where drug trafficking occurs;

c. customer demands investment management services with sources of investment funds that are uncertain or inconsistent with the credibility or financial potential of the customer;

d. Transactions with unknown counterparties or uncommon character, number and frequency of transactions;

e. Investors introduced by banks in other countries, related companies, or other investors from countries known to be manufacturing or selling drugs.

4. Suspicious transactions from international banking operations.

a. Introduction of customers through overseas branch offices, associated companies, or other banks based in a country considered to be a location for the manufacture or trading of narcotics;

b. Usage of letters of credit (L/C) and other trading instruments for foreign trading instruments to move funds between countries where the transaction is not in line with the business activities of the customer;

c. Receiving or sending customer transfers in large amounts to or from a country suspected to be linked to the manufacturing, processing and/or selling of illicit drugs or terrorist activities;

d. Accumulation of high balances which do not comply with the characteristics of the turnover of the customer, which are then moved to other countries;

e. Electronic transactions by customers without sufficient justification or by the use of an account;

f. High-frequency demands for checks on travellers, foreign currency notes or other negotiable instruments; 
g. Payments using traveller's checks or money orders in foreign currencies, in particular those provided by other high-frequency countries.

5. Suspicious transactions involving bank employees or agents.

a. Significant rise in the assets of employees and agents of the bank without sufficient explanation;

b. Transaction relationship by an entity who is not provided with adequate knowledge about the ultimate beneficiary.

6. Suspicious transactions by lending and borrowing transactions.

a. Unexpected repayment of non-performing loans;

b. Request for a loan facility with collateral, the origin of which is not evident from the assets pledged or not in compliance with the credibility and financial capability of the customer;

c. Customer requests banks to provide financing facilities where the portion of the customer's own funds in the facility is not clear where the origin of the customer's own portion of the funds in the facility is uncertain, particularly if it relates to property. ${ }^{24}$

Based on Law Number 8 of 2010, concerning Prevention and Eradication of the Crime of Money Laundering, Article 23 paragraph (1) states that Financial Services Providers are required to submit reports to PPATK, which include:

a. Suspicious financial transactions.

b. Cash financial transactions of at least Rp. 500,000,000, - (five hundred million rupiah) or in a foreign currency of equivalent value, which is carried out either in one transaction or in several transactions in one working day.

c. Financial transactions transfer of funds to and from abroad. ${ }^{25}$

Article 25 paragraph (5) of Law No. 8 Year 2010 on the Prevention and Eradication of Crime of Money Laundering requires PPATK to make regulations concerning procedures for the submission of suspicious financial transaction reports to financial service providers. In this regard, the PPATK has released a Regulation of the Head of the PPATK Number: PER-07/1.02/PPATK/12/10 on procedures for the submission of suspicious financial transaction reports to financial service providers where, in Article 2 paragraph (1) of CHAPTER II, the provider of financial services is necessary to send a Suspicious Financial Transaction (TKM) report to the PPATK.

24 Bismar Nasution, "Notary as a reporting party in the prevention and eradication of Money Laundering," (2018), 6 .

25 Law Number 8 of 2010 regulates the Prevention and Eradication of the Crime of Money Laundering, Jakarta. 
The TKM report submitted as referred to above, contains reports on termination of business relations with service users where:

a. Service users fail to comply with the concept of acknowledgment of service users;

b. PJK questions the quality of the information given by service users.

Whereas the submission of the TKM report must be done electronically or, in some cases, may be submitted non-electronically. In this regard, Ferry Aries Suranta claimed that it is possible to send suspicious financial transaction reports to PPATK in two ways: Manual and Electronic.

The Know Your Customer Principle can be used by Reporting Parties to define service customers' background and identity, track transactions, and report transactions to the competent authority (PPATK). Know Your Customer Principle is one of the ways to minimize national risks due to dynamics that occur nationally, regionally, and internationally, along with the production and distribution of goods, activities and information technology that can increase opportunities for the use of financial industry and financial institution facilities and products, particularly as a means of money laundering. The noble profession of notary and Land Deed Official (PPAT), when serving the public in the field of civil law, should not be used as a means of money laundering by criminals, as this would weaken the profession of notary and PPAT and would create a negative stigma in the eyes of the society.

In Government Regulation No 43 of 2015 concerning the Reporting Parties to the Prevention and Eradication of the Crime of Money Laundering, as set out in Article 3, it is stressed that the Notary profession is the party responsible for the suspected crime of money laundering committed based on the deed made by them. This Government Regulation is the enforcement of Article 17 paragraph (2) of the PPTPPU Law. There are two forms to report suspicious financial transactions, electronically and non-electronically. Reporting that can be performed electronically can be done by submitting reports to the telecommunications network through the Reporting Application, which is logged directly to the PPATK database. ${ }^{26}$

A notary is seen as a figure whose claims are reliable and trustworthy, whose signature and seal (seal) provide assurance and clear proof of the deed he makes. As long as the Notary Officer applies the provisions consistently, the notary will guarantee the execution of the precautionary measures for himself as a public

26 Putu Mas Maya Ramantini, Notary Responsibilities in Making Minuta Deeds Made Based on False Information by the Parties, Thesis (Denpasar: Faculty of Law, University of Udayana, 2004), 56. 
official. ${ }^{27}$

There are types of prudential principles that can be enforced by the notary during the deed-making process to prevent them from being trapped in legal difficulties, including:

a. Perform user identification. Notaries in carrying out their duties must be dealing with users making an authentic deed. Therefore, before making a deed, the notary must verify the users' identity, such as ID Card, Family Card, or Passport, and match the identity owner's photo with the users to avoid acts of falsification of identity against the deed made by the notary.

b. Carefully reviewing the user's subject and object data. The intent and objective are to check the subject data of the user whether or not they are allowed and competent to take legal action in order to comply with the legal requirements of the act, such as whether the user is at least 18 years old or married, as stipulated in point (a) of Article 39 paragraph (1) of the Law on Notary Role. Simultaneously, the process of validation of object data is the process of verifying object documents brought by the user, such as checking the validity of the land certificate to the National Land Agency or checking if the user concerned is a legitimate holder of the certificate.

c. Provide a grace period for the production of the authentic deed. The notary must provide a grace period so as not to hurry in making the deed and to be able to work slowly and thoroughly so as not to cause errors in the work of the Notary deed.

d. Make deeds prudently, cautiously, and thoroughly. This is important in the process of making deeds, particularly in words written on the deed. In reality, the notary sometimes becomes a concern because the terms are vague or cause misinterpretation.

e. Complies with all the technical criteria for notary deed to prevent signs of legal issues. This formal provision is laid down in Article 38 of the Law on Notary Positions, while the content requirements are codified in Article 1320 of the Civil Code.

f. Report to the relevant authorities any sign of money laundering in forming a deed.

27 Sam Dwi Zulkarnaen, the Principle of Prudence for Notaries as General Officials in Carrying Out Their Positions. Thesis (Depok: Notary Masters Program, University of Indonesia, Depok, 2008), 75. 


\section{Responsibilities and Legal Effects of Notaries in Applying the Principle of Knowing Your Customer}

The notary duty as a profession emerges from the presence of legitimate and bound duties and authority given to him. It is valid because the notary public pronounces his oath of office, and this oath should be capable of governing all the notary actions in the performance of his role. Raden Soegondo Notodisoerjo claimed that a notary must be held liable in the event of fraud or conspiracy in the execution of an act and that this can occur in a transfer of rights transaction, for example, deed of sale and purchase that knowingly involves a price lower than the actual price. ${ }^{28}$

The responsibilities of a notary are divided into four types, ${ }^{29}$ namely the responsibility of the notary in a civil manner regarding the material accuracy of the deed he has made

1. the notary is criminally responsible for the material truth in the deed made,

2. responsibility based on the Notary Position Regulation regarding the material accuracy in the deed made,

3. responsibility in carrying out his / her job duties based on the notary's code of ethics,

4. responsibility in a civil manner regarding the material accuracy in the deed made.

Responsibility for a person's actions usually only exists when that person commits actions that are not permitted by law, and most of these acts are illegal acts as regulated in the Civil Code; ${ }^{30}$

a. Acting against the law in a broad sense if the act violates the rights of others;

b. The law gives rights to everyone, (subjective recht rights) which in principle are given to protect their interests. Based on jurisprudence, the most important rights concerning illegal acts are personal rights such as the right to freedom, the right to honor, good name, and property rights;

c. Contrary to the perpetrator's legal obligations. Legal obligations are obligations that are given based on law and include written or unwritten things, and not only doing but also not doing something based on the law. If someone

28 Raden Soegondo Notodisoerjo, Notariat Law in Indonesia: An Explanation, second printing (Jakarta: RAJA Grafindo Persada, 1993), 229.

29 Nico, Responsibilities of Notaries as General Officials, Yogyakarta: Center for Documentation and Studies of Business Law (CDBL), (2003)

30 Abdul Ghofur Anshori, Indonesian Notary Institute, Legal Perspectives, and Ethics (Yogyakarta: UII Press, 2009), 38-39. 
does or does not commit an act contrary to what is mandated by law, it is against the perpetrator's legal obligation;

d. Contrary to good morality. The norms of decency apply to social life in society because social life in society is static, so the standard of decency is also not fixed (always changes). Things that were previously deemed unworthy now can be deemed appropriate, as well as things that were deemed unworthy today may later be deemed worthy; (e) it is contrary to the proper consideration of the self-interest and property of others in their daily life. Everyone has the same rights before the law; therefore it is appropriate to respect each other in enjoying each other's rights in daily life. An act that disregards the interests of others can be said to be contrary to propriety. Compliance is crucial for notaries to pay attention to in making or formulating a deed. Notaries must avoid making deeds in which one more party defends the interests by violating the other party's interests.

The notary is only formally responsible for an authentic deed he makes; therefore, the notary must be neutral towards the parties before him (client). Criminal responsibility of the notary for the deed he made

1. Law No. 02 of 2014 amending Law No. 30 of 2004 on the status of a notary (UUJN) does not control criminal provisions. UUJN only regulates penalties for offenses committed notaries against UUJN, the form of which lies in the act and the notary. When a notary is convicted, the deed's status immediately decreases from the genuine deed or becomes the deed under the hand. In contrast, the punishments issued to notaries include a notice of dishonorable discharge. Criminal activity is an act forbidden by the rule of law, and there are also criminal provisions for violation of the prohibition. Therefore, the penalty referred to here is a penalty for a notary as a professional public official who is allowed to conduct authentic actions prescribed by UUJN, not as an individual or as a notary as a legal subject.

2. The elements of a criminal act shall include (human) action. (1) Acts are activities and events that arise from a single act. Moeljatno claims that human involvement in the elements of a criminal act is actions plus behavioral events. He also claimed that: "in criminal law, there are positive (someone does something) and negative (someone does not do something that should be done) actions. Meanwhile, the meaning of action is a physical attitude, because not doing something cannot 
be included in that definition and what is included in the definition of action is limited to conscious physical attitude." (2) Fulfill the formulation of the law (formal requirements). An act can be said to be a criminal offense if it has fulfilled the formulation or elements contained in the regulation. This is based on the legal theory of 'nullum delictum nulla poena sine pravia lege poenali.' (3) Has an unlawful nature. Apart from the two elements above, it must also fulfill the third element, namely the element against the law, to be categorized as a criminal act. This element is an absolute element of a criminal act.

\section{Responsibilities of Notaries in Performing the Identification and Verification Process of Service User Data}

Regulation of the Minister of Law and Human Rights (Permenkumham) Number 9 of 2017 provides for the application of the Principle of Recognizing of Service Users for Notaries, which allows notaries to exercise additional authority, namely the identification, authentication, verification of the legitimacy of the identity of the user and the tracking of the source of the financial transactions of the user used to make the deeds. Apart from Permen, the rule is also mandated by Law No. 2 of 2014 on amendments to Law No. 30 of 2004 concerning the notary's role, namely creating authentic deeds and sequences.

Permenkumham states that notaries are obligated to determine the validity of the material identity and the legality of client transactions' supervision, such as the measures to be taken by the investigators. Article 2 Permenkumham paragraph 1 , 'Notary is obliged to apply the principle of recognizing of services users', which then, in paragraph 2, includes at least: ${ }^{31}(1)$ (1) Identification; ${ }^{32}$ (2) Verification; ${ }^{33}$

31 See Article 2 Permenkumham Number 9 of 2017, regulating the Application of the Principles of Recognizing Service Users for Notaries.

32 Identification of Service users as referred to in Article 10 Permenkumham Number 9 of 2017, among others: (a) In the case of collecting information regulating service users as referred to in Article 7, the Notary is obliged to examine the accuracy of the service user's identity document; (b) To ensure the correctness of the identity of the service user as referred to in paragraph 1 , the notary is obliged to meet in person with the service user.

33 Notaries verify information and documents before engaging in business relations with Service Users. The notary can make a business relationship or transaction before the verification process is complete if the notary has implemented risk management procedures. Suppose the Notary has a business relationship before the verification process is complete. In that case, the verification process must be completed as soon as possible, after the Service User has a business relationship with the Notary. Business relationships carried out with due regard to the risks of money laundering and terrorism financing can be managed effectively, and this face-to-face meeting process does not interfere with normal business activities. This is stated in Article 19 in conjunction with Article 20: (a). Notaries are required to 
(3) Tracking of transactions of services users. ${ }^{34}$

Another duty is imposed in Article 4 that, in applying the concept of recognizing of service users, a notary is obliged: (1) to provide policies and procedures for the management and prevention of the risk of money laundering and/or terrorist funding found following the risk assessment; and (2) Conduct a risk assessment by classifying service users based on the level of risk of a criminal act, such as money laundering and terrorism financing.

Article 2 specifies that notaries are obligated to recognize service users' concept through the identification, authentication, and monitoring of transactions in the deed-making process. In addition to the other duties mandated by the UUJN, this is an extra duty for the notary.

This application refers to notaries offering services in the form of planning and conduct of transactions for or on behalf of the Service User relating to the purchase and selling of goods, money management, securities and/or other financial services products, current account management, savings accounts, accounts deposits and/or securities accounts, transactions and/or transactions. This duty is carried out when the notary enters into a business arrangement with the Service User and notices specific characteristics, such as (a) the presence of financial transactions in rupiah currency and/or foreign currency, the value least or equal to $\mathrm{Rp} .100,000,000.00$ (one hundred million rupiahs), (b) there is a suspicious financial transaction that could be linked to the crime of money laundering and terrorist funding, or (c) the notary has doubts about the authenticity of the details reported by the Service User.

As stated in Article 4, notaries are required to provide policies and procedures to manage and mitigate the risks of money laundering and/or terrorist financing defined in compliance with risk assessments and to identify service users on the basis of their profile, business, country and product.

verify information and documents as referred to in Article 7, Article 8, Article 9, Article 11, Article 12, Article 13, Article 14, Article 15, Article 16, and Article 17; (b) The notary may request information from the Service User to find out the formal correctness of the Document as referred to in paragraph (1); (c) If the notary is in doubt as to the validity of the formal documents as referred to in paragraph (2), the Notary may request other supporting documents from the authorized party.

34 Notaries monitor the fairness of Transactions of Service Users. A Notary Public is responsible for recording transactions and information systems regarding identification, monitoring, and provision of reports on transactions made by Service Users, in terms of transaction recording and information systems. Recording of transactions and information systems can be done non-electronically or electronically according to each notary's complexity and characteristics. 
In addition to the above responsibilities, it is also forbidden for notaries to open or retain anonymous accounts or accounts that use fake names, including proof of business relationship accounts between notaries and service users (Article 5).

Reporting responsibilities addressed to these professions and agencies shall be used as a gatekeeper for transactions or activities involving data or information. One of the occupations that may serve as a gatekeeper is a notary, and to fulfill its responsibilities is governed in Article 3 of Government Regulation No 43 of 2015 on Reporting Parties to the Prevention and Eradication of Money Laundering, and notaries are responsible for alleged money laundering or on behalf of service users.

In practice, notaries are also asked to testify on legal forgery, material law, and intellectual law. Intellectual law forgery, for example, offers false information on a notary's deed aimed at concealing the proceeds of illicit money suspected of coming from money laundering. ${ }^{35}$

It is also important to prevent and eliminate any crime that has been found to have been used in the service of a notary in conjunction with assets originating from criminal actions. As specified in Article 54 UUJN, "Notaries may only give, show or notify the contents of the deed, gross deed, copy of the deed or excerpt of the deed to persons with a direct interest in the deed, the heirs or the persons who obtain the rights, except as provided for in the statutory provisions."

The information system that is owned allows the notary to track every transaction if necessary, both for internal purposes and/or the ministry that carries out matters in the legal field, as well as concerning law enforcement So, for example, the notary has tried to apply the precautionary principle as stated in Article 16 letter a of the UUJN "in carrying out his position, the notary is obliged to act trustworthy, honest, thoroughly, independent, not taking sides, and safeguarding the interests of the parties involved in legal actions."

Notaries are also required to apply the principles set out in Permenkumham Number 9 of 2017 Article 21 "notaries are required to monitor the fairness of service user transactions," whether the transaction is suspicious by requesting additional documentation for applying the precautionary principle.

Suppose the client or prospective customer (service user) refuses to provide the paper. In that case, the notary is obliged to terminate the business arrangement with the service user since the service user refuses to comply with the principle of acceptance of the service user or the notary has doubts about the quality of the

35 Tian Terina and Rendy Renaldy, "Problems of Notary Obligations in Reporting Suspicious Financial Transactions", Repertorium: Notary Law Scientific Journal. No. 8 (2020): 28. 
information given by the service user. Even then, the notary is obliged to report to PPATK reg. Reporting shall occur as soon as possible, no later than three working days after the notary becomes aware of the suspicious financial transaction.

The notary is also obliged to stop the application of the principle of recognizing of users services when the transactions carried out are suspected of having ties to money laundering and terrorist financing; and the notaries believe that the enforcement of the principle of identification of users of services that is being carried out violates the anti-tipping provisions. Such transactions must be identified as Suspicious Financial Transactions to PPATK, and the notary has the right to decide to reject and continue to report the transaction via an analysis of Service User Transactions either duties of a notary, as provided for in Article 22, paragraph 1, "notary is responsible for the recording of transactions and information systems regarding identification, monitoring, and provision of reports on transactions made by service users." In conjunction with Article 23 paragraph 1, which reads "notary shall be obliged to administer all documents of service users and beneficial owners."

PPATK was established to prevent and eliminate money laundering, including numerous criminal activities that generate illegal assets and other serious crimes, by providing intelligence information resulting from the review of reports. In order to carry out these key tasks, PPATK is obliged, among other things, to draw up guidelines for financial service providers $(\mathrm{PJK})$ in order to identify the conduct of financial service users engaged in suspicious financial transactions. ${ }^{36}$

The duty to report suspicious financial transactions by professionals such as notaries to PPATK, as stipulated in Government Regulation No 43 of 2015 on Reporting Parties to the Prevention and Eradication of Money Laundering, is then legalized as a Notary's obligation. Government Regulation No 43 of 2015, concerning the Reporting Parties to the Prevention and Eradication of Money Laundering, is contrary to the provisions concerning the duty of notaries to maintain confidentiality, as set out in Article 16 Paragraph (1) letter (f) of the UUJN, so that it may give rise to legal confusion, because the legal system does not contain rules that contradict each other, and this issue is vital in this study, due to the hierarchy of laws and regulations. The laws and regulations of a country do not allow or authorize any dispute or conflict in it. The legitimacy of the hierarchy in the statutory legislation, the concept of lex superior derogat legi inferiori, lex

36 Nurananda Budi Muliani et al "Responsibilities of Notaries as Reporters of Suspicious Financial Transactions in the Gathering Report \& Information Processing System (GRIPS) Application" Undergraduate thesis, University of Indonesia, 2019. http://lib.ui.ac.id/ 
specialis derogat legi generalis, lex posteriori derogat legi priori shall also apply. ${ }^{37}$

The author takes some notary opinions on the identification and verification of service user data as set out in Permenkumham Number 9 of 2017, concerning the Principles of Recognizing of Service Users, and the results are as follows:

According to Feliyanti, $\mathrm{SH}$ as a notary, it is challenging to enforce these rules considering that there are several items governed in the UUJN, that is, in Article 16, point (f) that "in carrying out his or her office, notaries are required to retain all the deeds they have made, and all the details gathered for making deeds following the oath or promise of office unless the law provides otherwise."

Furthermore, as regards the concept of recognizing service users by notaries in Permenkumham, it is considered very precise and limits the notary's freedom; for example, the notary must ensure that the user's identity is accurate. This is not the authority of the notary. However, the authority of the police, since what is communicated by the notary is considered valid. The notary does not have to clarify the validity of the customer's identity, if this is not done, it will affect the notary service (time frame for making deed). In addition, the authority of the notary is hierarchically governed by UUJN, where the legal criteria for a notarial act are to comply with Article 38, not identification and verification, as specified in Permenkumham. The role of Permenkumham as a supplement to notaries in the making of notarial deeds is therefore mandatory and must also be respected. ${ }^{38}$

Imam Rahmat Syafaat, S.H., said that the regulation, which discusses suspicious financial transactions, is very burdensome for notaries because what is mentioned in Permenkumham No.9 of 2017 focuses on investigators' authority. The position of UUJN for notaries in a hierarchical manner is intended to prove the formal facts, while the material truth of the data of notary service users is the investigator's responsibility. However, as a form of implementing the precautionary principle, the notary must have useful techniques to ensure that clients (consumers) do not feel disadvantaged. ${ }^{39}$

Similarly, the notary's passive authority in the fulfillment of these obligations should be reconsidered, since the nature of the active-duty must be fulfilled by the active authority so that the notary can function optimally to assist PPATK. ${ }^{40}$

37 Tian Terina and Rendy Renaldy, "Problems of Notary Obligations in Reporting Suspicious Financial Transactions", Repertorium: Notary Law Scientific Journal. No. 8 (2020): 31.

38 Interview with the regional notary supervisory board of Magetan Regency, Feliyanti, SH, about notaries' responsibilities in implementing service user identification, on June 12, 2020.

39 The results of an interview with Imam Rahmat Sjafi'i SH., Notary of Malang City, about the principles of recognizing service users, on 13-06-2020.

40 Teuku Ulya Murtadha et al, "The Notary's Obligation to Report Suspicious Transactions in the Prevention and Eradication of Money Laundering", Syiah Kuala: Law Journal. Vo. 3 (2019): 377. 
PPATK, as a financial intelligence unit for the prevention and eradication of money laundering in Indonesia, is complying with Law No 8 of 2010 on the prevention and eradication of money laundering in Article 41 paragraph (1): "in carrying out the role of prevention and eradication of money laundering as referred to in Article 40 letter (a), PPATK is allowed to: (a) request and obtain data and information from government agencies and private private institutions that have the authority to handle data and information, including government agencies and/or private institutions that collect reports from certain professions; (b) set standards for the detection of suspicious financial transactions; (c) organize efforts to prevent money laundering with related agencies; (d) make recommendations to the Government on measures to prevent money laundering; (e) represent the Government of the Republic of Indonesia in international organizations and discussion forums on the prevention and eradication of money laundering; ( $f$ ) provide education and practical training programs on money laundering; and $(\mathrm{g})$ coordinate socialization of prevention and eradication of the crime of money laundering."

The above article indicates that PPATK plays a significant and strategic role in Indonesia's asset recovery program, in particular in providing intelligence information for asset monitoring in the financial sector, both during the financial transaction analysis process and during the investigation, prosecution, and examination process of the defendant in court. ${ }^{41}$

In order to carry out the analysis function (Article 44) and as an effort to eradicate the crime of money laundering, the Law on Prevention and Eradication of the Crime of Money Laundering regulates that reporting parties are required to submit reports to PPATK (Article 17 paragraph 1), Law Number 8 2010, concerning the Prevention and Eradication of Money Laundering, among others: (a) financial service providers; (1) bank; (2) finance company; (3) insurance companies and insurance brokerage companies; (4) pension fund financial institutions; (5) securities companies; (6) investment manager; (7) custodian; (8) trustee; (9) postal service as a current account service provider; (10) foreign exchange traders; (11) card-based payment instrument operators; (12) e-money and/or e-wallet operators; (13) cooperatives, which are engaged in savings and loans business; (14) pawnshops; (15) companies engaged in commodity futures trading; or (16) business operators in the money remittance sector. (b) Providers

41 Toetik Rahayuningsih, "Analysis of the Role of PPATK as an Institution in Tackling Money Laundrying in Indonesia", Yuridika. Vol. 28 (2013): 317. 
of other goods and or services: (1) Property agent property companies; (2) Motor vehicle traders; (3) precious metal jewelry and gem traders; (4) Art and antique merchants; or (5) auction hall.

Based on the provisions of the reporting party referred to above, it can be seen that UUTPPU assigns its responsibilities to financial services, products and/ or services providers to submit reports to PPATK. In addition, the Reporting Parties pointed in the provisions of the Law referred to above have been renewed in Government Regulation No 43 of 2015 on Reporting Parties to the Prevention and Eradication of the Crime of Money Laundering (hereinafter referred to as PP 43/2015), which states that "lawyers, notaries, land deed officers, accountants, public accountants, and financial planners are among the Reporting Parties."

In its development, the practice of money laundering crosses jurisdictional borders and has varied ways of using financial institutions outside the financial system, and has also entered multiple sectors.

Apart from the presence of international pressure, progress, and changes in the anti-money laundering laws in Indonesia are also affected by legal consciousness that money laundering harms the national economy. ${ }^{42}$ In addition, the provision of money laundering as a criminal would allow law enforcement authorities to confiscate proceeds of crime that have sometimes been passed to third parties.

In relation to notaries' duties in the oath of office, it is stipulated that notaries must keep the contents of the document confidential in compliance with the provisions of Article 16, paragraph 1, letter f of the UUJN, and Article 54 UUJN. Holding the document secret contents is a legal and ethical principle for notaries as to the existence of confidentiality inherent in the information. ${ }^{43}$

In relation to notaries' duties in the oath of office, it is stipulated that notaries must keep the contents of the document confidential in compliance with the provisions of Article 16, paragraph 1, letter f of the UUJN, and Article 54 UUJN. Holding the document secret contents is a legal and ethical principle for notaries as to the existence of confidentiality inherent in the information.

In connection with the notary deed, the provisions of Article 1 number 7 of Law Number 2 of 2014, concerning the Position of Notary Public (UUJN), stipulate that the notary deed is authentic, made by or before a notary, following the form and procedure stipulated in the law. Based on this provision, the deed made by (door) notary is called deed of relaas or deed of minutes, which contains a description of the notary seen and witnessed by the notary himself at the user's

42 Bismar Nasution, Op. Cit., hal.15-16

43 Tian Terina and Rendy Renaldy, "Problems of Notary Obligations in Reporting Suspicious Financial Transactions", Repertorium: Notary Law Scientific Journal. No. 8 (2020): 27. 
request, so that the actions or actions taken by the user are written into a notary deed. Deeds made before (ten overstaan) notaries, in notary practice, are called party deeds because they contain descriptions, statements, and statements from users given or told in front of a notary. ${ }^{44}$

Furthermore, the provisions of Article 38 paragraph (3) letter $\mathrm{c}$ of the UUJN confirm that the contents of the deed are the will and wishes of the user who comes before a notary public. Thus, the deed contents are stated materially as the will or wishes of the clients themselves, not the will or wishes of the notary, and the notary only provides a frame in the form of a notary deed that is under UUJN and must provide advice. Therefore, if the deed contents are disputed by people or other interested parties related to the contents of the deed, this is the user's responsibility. ${ }^{45}$ Notaries are obliged to keep all information provided by the user confidential, even if there are things not included in the deed. The obligation to keep secret for notaries is not only a mandate from the law, but the ethics of a notary to maintain public trust (vertrouwenspersoon) as a public official. ${ }^{46}$

Notaries are obliged to keep all information provided by the user confidential, even if there are things not included in the deed. The obligation to keep secret for notaries is not only a mandate from the law, but the ethics of a notary to maintain public trust (vertrouwenspersoon) as a public official. ${ }^{47}$

Pitlo, a trusted person, does not have the right to just exercise his denial according to his will. This obligation to keep confidential has a strong public legal basis (een publiekrechtelijke inslag). Even though it is “in concreto," an individual gets benefits from it, but the obligation to keep it secret is not borne to protect that individual. However, it is imposed for the benefit of the general public. Thus, it is clear how the protection of individual interests always has a public interest background. The general public's confidant must consider what is a specific matter should take precedence, the interests of the general public plus the interests of the individual in that he is not allowed to talk about it or the interests of the community which in his capacity he may speak about it. ${ }^{48}$

In the FGD (Forum Group Discussion) in Medan, PPATK conveyed the reasons for the notary being made the reporting party in the TPPU, including: (a)

44 Habib Adjie, Knitting Thoughts in the World of Notaries \& PPAT (Bandung: PT. Citra Aditya Bakti, 2014), 10.

45 Habib Adjie, Knitting Thoughts in the World of Notary \& PPAT, 30.

46 Habib Adjie, A collection of writings: Weaving opinions about notary (Bandung: PT. Citra Aditya Bakti, 2013), 132.

47 G.H.S Lumban Tobing, Regulation of the Position of Notary Public (Jakarta: Erlangga, 1999), 118.

48 G.H.S Lumban Tobing, Regulation of the Position of Notary Public, 124. 
the results of typological research and cases of money laundering in the world show that gate keepers or certain professions, such as lawyers, notaries, PPAT, accountants, public accountants, and financial planners are used by money launderers to obscure the origin of money or funds that actually originate from criminal acts; (b) the profession of advocates, notaries, PPATs, accountants, public accountants and financial planners are prone to take advantage of confidentiality provisions that are provided based on rules such as confidentiality between certain professions and clients as a tool in money laundering schemes; (c) protect the profession of lawyers, notaries, PPATs, accountants, public accountants, and financial planning from criminalization of money laundering; (d) Recommendation Number 23, issued by the Financial Action Task Force (FATF), states that certain professions that carry out suspicious financial transactions for the benefit of or for and on behalf of service users are obliged to report the transaction to the financial intelligence unit (in this case is the PPATK). ${ }^{49}$

Notaries, as positions trusted by the public, are obliged to keep secrets regarding the deeds they have made, and information, or statements from users obtained in making deeds, except the law that instructs them to disclose secrets, and provide such information, or statements to the party who requested it. The authority of the notary as a public official, in connection with the obligation to keep the contents of the deed confidential and all other information which in the making of the deed, provides free space or loopholes for the movement of funds from the proceeds of crime through services provided by the notary, which are then used by the perpetrators to carry out money laundering activities. This includes one of the methods or methods used by the perpetrators of money laundering through non-financial institutions.

The notary's authority over the obligation to keep the contents of the deed confidential and all information in the drafting of the deed is related to the mandate concept. In Islam the mandate is regulated in Chapter 4, Verse number 58, which means "Indeed, Allah commands you to return trusts to their rightful owners; and when you judge between people, judge with fairness. What a noble commandment from Allah to you! Surely Allah is All-Hearing, All-Seeing."

The verse from the Al Quran above explains that a notary as a public office is trusted by the user (client). In the process of making the deed, he must protect the contents of the deed so that it is not known by others. In this concept, it is in line with mandate, defined by something that is entrusted by others to be carried out. Article 16 paragraph 1 letter UUJN also explains that notaries are obliged

49 Muhammad Sigit. Importance of PMPJ, GRIPS, and Reporting for Notaries, Forum Group Discussion, PPATK, March 08, 2019. 
to use the "right of refusal" to parties who have no interest in the contents of the authentic deed.

With the increasingly strict banking institutions in carrying out their business activities, criminals are forced to shift the mode of money laundering through buying and selling real estate (property). This method also involves notaries and money laundering in making deeds directly or indirectly. The use of the notary profession and the money laundering in conducting money laundering by criminals has had various negative impacts on the state and the notary profession and the money laundering itself. Therefore, a more vigorous legal reform needs to be formed to prevent and eradicate money laundering Apart from its function to prevent and eradicate money laundering offenses, this regulation also provides legal protection to notaries and PPAT in carrying out their positions overshadowed by the PPTPPU Law.

\section{Conclusion}

Suspicious financial transactions are financial transactions that deviate from the profile, characteristics, or daily transactions in general and with large nominal values worthy of suspicion. It could be that the money used in a transaction using the services of a notary is a deposit and comes from illegal sources of funds. The criteria and characteristics of suspicious financial transactions are usually carried out by other people, power of attorney, and transactions through banking media.

The responsibility and legal consequences of notaries in applying the Know Your Consumer principle, which is only in the form of identification and verification of service users, and notaries do not have the responsibility to determine the correctness of the material because the notary's obligation only determines formal requirements, namely being known or introduced to the user as a condition for making authentic deed regulated by UUJN. In addition, the notary must also apply the prudential principle in the deed-making process, among others by recognizing the identity of the user, verifying data from the user, both identity and other supporting data carefully, giving grace to work on deeds, acting carefully, thoughtfully, and be thorough in the deed work process, comply with all technical requirements for making deeds, and report any indication of money laundering in the transaction process. Material truth will not affect the deed made by a notary because a notary deed's legal requirements are stated in the UUJN. However, suppose the material truth is not carried out by applying the precautionary principle. In that case, the notary will receive administrative sanctions against TKM, 
or not reporting, as regulated in Articles 29 and 30, regarding the Regulation of the Head of PPATK, which is Suspicious for the profession, which is following the mandate. Permenkumham No. 9 of 2017, concerning the Application of the Principles of Recognizing Service Users for Notaries.

\section{References}

Abdulkadir, Muhammad. Hukum Perusahaan Indonesia. Bandung: PT. Citra Aditya Bakti, 2018.

Adjie, Habib. Kumpulan Tulisan: Menjalin Pemikiran-Pendapat Tentang Kenotariatan. Bandung: PT.Citra Aditya Bakti, 2013.

Adjie, Habib. Merajut Pemikiran dalam Dunia Notaris \& PPAT. Bandung: PT.Citra Aditya Bakti, 2014.

Anshori, Abdul Ghofur. Lembaga Kenotariatan Indonesia. Yogyakarta: UII Press, 2009.

Black, Henry Campbell. Black's Law Dictionary Sixth Edition, St. Paul Minn. West Publishing Co., 1990.

Budiarto, Agus. Kedudukan Hukum dan TanggungJawab PendiriPerseroan Terbatas. Bogor: Ghalia Indonesia, 2009.

David Chaikin and J.C Sharman. Corruption and Money Laundering. United States: Palgrave Macmillan, 2009.

Florenshia. "Analisis Yuridis Terhadap Kewajiban Notaris Dalam Melaporkan Transaksi Keuangan Yang Mencurigakan Dalam Rezim Anti Money Laundering”. Premise Law Jurnal, Vol. 9 (2019).

Ganarsih, Yenti. Penegakan Hukum Anti Pencucian Uang dan Permasalahan di Indonesia. Jakarta: PT Rajagrafindo Persada, 2015.

Husein, Yunus. "Perkembangan Terkini Rezim Anti Pencucian Uang Indonesia", https://yunushuesein.wordpress.com (2020).

Hutagalung, Daniella Herera Yosifany. "Perlindungan Hukum Terhadap Notaris Dan Ppat Sebagai Pihak Pelapor Dalam Tindak Pidana Pencucian Uang”. Jatiswara, Vol. 35 No. 1 (2020).

Jahja, Juni Sjafrien. Melawan Money Laundering. Jakarta: Visi Media, 2012.

M.U Sembiring. Teknik Pembuatan Akta. Program Pendidikan Spesialis Notariat Fakultas Hukum Universitas Sumatera Utara, 1997.

Mardi. Sistem Informasi Akuntansi. Bogor: Penerbit Ghalia Indonesia, 2011. 
Mhd. Syahman Sitompul, Nurlaila, Hendra Harmain. "Implimentasi Surat al-Baqarah Ayat 282 Dalam Pertanggungjawaban Mesjid Di Sumatera Timur”, Human Falah: Volume 3. No. 2 (2016).

Nadapdap, Binoto. Hukum Perseroan Terbatas, Jakarta: Permata Aksara, 2012.

Nasution, Bismar. "Notaris sebagai pihak pelapor dalam pencegahan dan pemberantasan Money Laundering", (2018).

Nico. Tanggungjawab Notaris Selaku Pejabat Umum. Yogyakarta: Center for Documentation and Studies of Business Law (CDBL), 2003.

Notodisoerjo, Raden Soegondo. Hukum Notariat di Indonesia suatu Penjelasan, Cet. Kedua. Jakarta: Raja Grafindo Persada, 1993.

Nurananda Budi Muliani, dkk. "Tanggung Jawab Notaris Sebagai Pelapor Transaksi Keuangan Mencurigakan Dalam Aplikasi Gathering Reports \& Information Processing System (Grips)". Notary, Vol 1, No 003 (2019).

PPATK. "Buletin statistik Anti Pencucian dan Pendanaan Terorisme". Volume 103 (2018).

Rahayuningsih, Toetik."Analisis Peran PPATK Sebagai Salah Satu Lembaga Dalam Menanggulangi Money Laundrying di Indonesia”, Yuridika. Vol. 28 (2013).

Ramantini, Putu Mas Maya. “Tanggung Jawab Notaris Dalam Pembuatan Minuta Akta yang Dibuat Berdasarkan Keterangan Palsu Oleh Para Pihak”. Tesis. Denpasar: Fakultas Hukum Universitas Udayana, 2004.

Sapulete, Raisa Maria. “Transaksi Keuangan Mencurigakan Menurut Undang-Undang Nomor 8 Tahun 2010 Tentang Anti Pencucian Uang”, Lex et Societatis, Vol.1 No 2 (2013).

Saragih, Ira Quwaity “Analisis Yuridis Kewajiban Notaris Merahasiakan Akta Terkait Pasal 3 Peraturan Pemerintah Nomor 43 Tahun 2015 Mengenai Notaris Sebagai Pihak Pelapor Dalam Pencegaha Dan Pemberantasan Tindak Pidana Pencucian Uang". Premise Law Jurnal, Vol 13 (2013).

Sigit, Muhammad. Pentingnya PMPJ, GRIPS dan Pelaporan Bagi Notaris, Forum Group Discussion, PPATK, 08 Maret 2019.

Teuku Ulya Murtadha dkk. "Kewajiban Notaris Melaporkan Transaksi Mencurigakan Dalam Pencegahan dan Pemberantasan Tindak Pidana Pencucian Uang," Syiah Kuala: Law Journal. Vo. 3 (2019).

The Law No. 8 of 2010 concerning the Prevention and Eradication of Money Laundering

The Regulation of the Minister of Law and Human Rights, Number 9 of 2017, 
concerning the Principles of Recognizing Service Users for Notaries (known as $P M P J)$

Tian Terina dan Rendy Renaldy, "Problematika Kewajiban Notaris Dalam Melaporkan Transaksi Keuangan Mencurigakan”, Repertorium: Jurnal Ilmiah Hukum Kenotariatan. No. 8 (2020).

Tobing, G.H.S Lumban. Peraturan Jabatan Notaris. Jakarta: Erlangga, 1999.

Wiyono.Pembahasan Undang-undang Pencegahan dan Pemberantasan Tindak Pidana Pencucian Uang. Jakarta: Sinar Grafika, 2014.

Zulkarnaen, Sam Dwi. "Prinsip Kehati-hatian Notaris Sebagai Pejabat Umum Dalam Melaksanakan Jabatannya”. Tesis. Depok: Program Magister Kenotariatan Universitas Indonesia, 2008. 